\title{
Utilization of cereals in early weaning diets for piglets: comparison of harley and wheat and efficiency of flaking and expansion
}

\author{
A. AUMAITRE and R. II:MOND*
}

\author{
Station de Recherches sur l'Élevage des Porcs, I. N.R. A., C. N. R. Z., \\ 78350 Jouy en Josas \\ * Sté des produits du Maïs, \\ 92 Clamart
}

Three successive experiments were made. The first one concerned the effect of the type of cereals (wheat, barley or a mixture of both) and the two others delt with the influence of three moist-heat treatments : flaking and popping applied to barley or maize and cooking-extrusion of maize semolina on the performances of early weaned piglets. The feeds were incorporated into the diets at a level of 57-59 p. Ioo and the piglets were weaned at 35 or 21 days.

The first experiment was made on 6 groups of animals, between 5 and 9 weeks of age at the beginning of the studly. The expcrimental scheme used was that of the balanced incomplete blocks of type I allowing comparison of 3 treatments within the same litter. Analysis of the results obtained with 6 diets offered to 2 contemporary litters showed that the diet based on barley was superior to that containing solely wheat. The growth performances $\left(45^{8}\right.$ versus $\left.392 \mathrm{~g} / \mathrm{day}\right)$ and feed intake ( 780 versus $643 \mathrm{~g} /$ day) were significantly different whereas the food conversion ratio varied only slightly. The performances of the piglets fed a barley and wheat diet were located between the extreme values. According to this, barley is supposed to be one of the best cereals to be incorporated into the diets of piglets weaned at 5 weeks.

The two other experiments regarding the influence of three moist-heat treatments of the ccreals on the animals' performances were mitle by means of complete blocks of animals weaned at 2 I days. The results showed that the flaking of barley had a favourable effect on the piglets growth performances, stimulated at the same time the feed intake and reduced the feed conversion ratio. This influence was particularly marked during the two weeks following weaning, whereas the popping treatment did not have any significant effect. The results also showed that cookingextrusion of maize semolina had a favourable effect on the growth performances and improved the feed intake level, whereas the flaking and popping of muize did not have any effect. Moist-heat treatments of the cereals had a spectacular effect on the improvement of the apparent digestibility of the main nutrients in the diet (dry matter, organic matter and crude protein). Thus, flaking or popping increased by about 4.5 points (i. e. $6 \mathrm{p}$. Ioo) the apparent mean digestibility of protein in the cliet based on barley and by 3.3 point: $(i . e .+.2$ p. 100) the apparent mean digestibility of protein in the diet based on maize.

Improvement of the digestibility was especially marked during the two weeks following weaning ( $2 \mathrm{I}-35$ days). The extrusion treatment only led to a slight, non significant improvenent of the digestibility of the diet

According to the results obtained, the choice of the cereals to be incorporated into early weaning dicts is important, but moist-heat treatments, because of their high cost price, should not be applied even if they improve the digestibility of the feeds. Consequently, granulation, involving heat treatment of a rich starch feed, remains extremely valuable for feeds used in piglet diets. 